\author{
Mojtaba BIGLAR ${ }^{1}$ \\ Feliks STACHOWICZ \\ Tomasz TRZEPIECIŃSKI ${ }^{3}$ \\ Magdalena GROMADA ${ }^{4}$
}

\title{
AKTYWNE TEUMIENIE DRGAŃ PŁYTY PROSTOKĄTNEJ ZA POMOCA PIEZOELEKTRYCZNYCH ELEMENTÓW POMIAROWYCH ORAZ WYKONAWCZYCH
}

\begin{abstract}
W artykule analizowano proces aktywnego tłumienia drgań płyty prostokątnej wykorzystując piezoelektryczne elementy pomiarowe i wykonawcze. Do ustalenia optymalnej pozycji i orientacji piezoelektrycznych elementów pomiarowych oraz wykonawczych wykorzystano algorytm genetyczny. Do aktywnego tłumienia drgań płyty opracowano algorytm sterowania ujemnego prędkościowego sprzężenia zwrotnego. Przeprowadzono wiele symulacji aby wykazać przydatność algorytmu genetycznego wykorzystanego do optymalizacji lokalizacji oraz orientacji elementów piezoelektrycznych zamocowanych do cienkiej płyty. Założono, że piezoelektryczne elementy pomiarowe oraz wykonawcze są idealnie połączone $\mathrm{z}$ powierzchnią płyty. Podczas analiz obciążeniowych zastosowano funkcję krokową koncentrując obciążenie w miejscu leżącym poza środkiem płyty. Po umieszczeniu elementów piezoelektrycznych w optymalnej lokalizacji, amplitudy drgań płyty ulegały zmniejszeniu. Analizowano również wpływ liczby urządzeń piezoelektrycznych na właściwości aktywnego tłumienia systemu. Podsumowując, wykorzystanie kilku elementów pomiarowych oraz wykonawczych pozwala uzyskać wzrost efektu tłumienia i bardziej efektywne zmniejszenie amplitudy drgań płyty.
\end{abstract}

Słowa kluczowe: element wykonawczy, aktywne sterowanie drganiami, algorytm genetyczny, czujnik piezoelektryczny, gramian

\section{Wstęp}

System aktywnego sterowania drganiami odgrywa istotną rolę w kontroli odkształceń konstrukcji lotniczych. System ten, w odniesieniu do drgań ogona samolotu wojskowego, po raz pierwszy został opracowany przez firmę Active

\footnotetext{
${ }^{1}$ Autor do korespondencji/corresponding author: Mojtaba Biglar, Politechnika Rzeszowska, Al. Powstańców Warszawy 12, 35-959 Rzeszów, tel.: (17) 74324 58, e-mail: m_biglar@prz.edu.pl

2 Feliks Stachowicz, Politechnika Rzeszowska, e-mail: stafel@prz.edu.pl

${ }^{3}$ Tomasz Trzepieciński, Politechnika Rzeszowska, e-mail: tomtrz@prz.edu.pl

${ }^{4}$ Magdalena Gromada, IE-IB, Oddział Ceramiki CEREL Boguchwała, e-mail: gromada@cerel.pl
} 
Controls eXpert na zamówienie US Air Force. W skład systemu wchodzi piezoelektryczny odkształcalny element wykonawczy, który stanowi główną część układu oraz czujniki przyśpieszeń i odkształceń dostarczające informacje do kontrolera opartego na DSP (ang. Digital Signal Processing). Obecnie układy piezoelektryczne w zastosowaniach do sterowania drganiami są stosowane, m.in. w medycynie (czujniki do pomiaru ciśnienia krwi), sporcie (aktywny tłumik drgań zastosowany w rowerze górskim, tłumik drgań w desce snowboardowej, nartach wodnych lub kiju baseballowym), technice (sterowanie klapami skrzydeł, aktywatory, piezo-zawory, silniki ultradźwiękowe, termoregulatory), budownictwie (aktywne tłumienie drgań i hałasu, maty detekcyjne) oraz robotyce (sztuczne mięśnie robota). Dwie najważniejsze cechy decydują o zastosowaniu elementów piezoelektrycznych jako tłumików drgań, tj.:

- piezoelektryki posiadają dużą sztywność mechaniczną, warunkując bardzo dobre przenoszenie energii mechanicznej do piezo-amortyzatora,

- materiały piezoelektryczne przekształcają drgania w energię elektryczną konieczną do wytworzenia częstotliwości drgań aktywującej tłumik elektroniczny.

Integralną częścią aktywnego układu do aktywnego tłumienia drgań płyt jest aktywator (element wykonawczy). Aktywatory mogą występować w kilku postaciach. Aktywator odkształceń jest cienką, płaską płytką, umieszczaną na powierzchni badanej struktury za pomocą spoiwa. Aktywator odkształceń, poprzez wzbudzenie sygnałem oscylacyjnym może wywoływać drgania. Bimorf jest elementem wielowarstwowym, w skład którego wchodzi dwa niezależne elementy piezoceramiczne, które odkształcają się niezależnie w dwóch przeciwnych kierunkach. Jedna z warstw rozciąga się, a druga kurczy, wywołując odchylenie części giętkiej elementu wykonawczego.

Konieczność stosowania aktywnego tłumienia drgań występuje w szczególności w dużych elastycznych strukturach lotniczych $[9,11]$. Ustalenie lokalizacji elementów pomiarowych oraz wykonawczych jest kluczowym zadaniem, zwiększającym sprawność systemu. Kumar i Naryanan [5], wykorzystując liniowy regulator kwadratowy (ang. Linear Quadratic Regulator) do aktywnego tłumienia drgań, określili optymalną lokalizację elementów pomiarowych oraz wykonawczych w belce odkształcanej. Sadri i in. [8] zaproponowali dwa kryteria do określenia lokalizacji elementów wykonawczych piezoelektrycznych wykorzystując gramiany sterowalności oraz obserwowalności. Halim i Moheimani [3] opracowali kryterium do znalezienia optymalnego położenia połączonych ze sobą par element pomiarowy/wykonawczy na cienkiej płycie odkształcalnej. Jednakże w pracy tej nie zostały określone analitycznie równania ruchu oraz nie wykorzystywano algorytmu sterowania do tłumienia drgań płyty. Brunet $i$ in. [1] wykorzystali algorytm genetyczny do wyznaczenia optymalnych lokalizacji elementów pomiarowych oraz wykonawczych na płycie prostokątnej. He i in. [4] zaproponowali zastosowanie metody elementów skończonych do sterowania drganiami płyt o właściwościach gradientowych FGP (ang. Functionally Graded 
Plate) na podstawie klasycznej teorii płyt warstwowych CLPT (ang. Classical Lamination Plate Theory).

$\mathrm{W}$ artykule zaproponowano nowe podejście do aktywnego tłumienia drgań płyty prostokątnej oraz określenie optymalnych lokalizacji i orientacji piezoelektrycznych elementów pomiarowych oraz wykonawczych. Na podstawie klasycznej teorii płyt CPT (ang. Classical Plate Theory) i równań teorii liniowych elementów piezoelektrycznych wyprowadzono równania ruchu oraz równania sygnałów wyjściowych czujników wykorzystując prawo Hamiltona i procedurę aproksymacji Rayleigh-Ritza. Celem zwiększenia sprawności systemu ustalono optymalne lokalizacje elementów pomiarowych oraz wykonawczych na podstawie gramianów sterowalności i obserwowalności oraz wykorzystując algorytm genetyczny (AG). Do aktywnego tłumienia drgań płyty opracowano algorytm sterowania ujemnego prędkościowego sprzężenia zwrotnego.

\section{Lokalizacja elementów piezoelektrycznych}

Rozważmy odkształcalną płytę (rys. 1) z $N_{a}$ piezoelektrycznymi elementami wykonawczymi i $N_{s e}$ piezoelektrycznymi elementami pomiarowymi. Całkowita energia potencjalna płyty i elementu piezoelektrycznego jest równa [6]:

$$
\begin{aligned}
P E=\int_{V^{s t}} \frac{1}{2} S^{T} & c_{s t} S \mathrm{~d} V^{s t} \\
& +\sum_{j=1}^{N_{a}} \int_{V_{j}^{a}}\left(\frac{1}{2} \tilde{S}^{T} c^{D} \tilde{S}-\tilde{S}^{T} h \widetilde{D}^{j}+\frac{1}{2} \widetilde{D}^{j T} \beta_{s} \widetilde{D}^{j}\right) \mathrm{d} V_{j}^{a} \\
& +\sum_{j=1}^{N_{s e}} \int_{V_{j}^{s e}}\left(\frac{1}{2} \tilde{S}^{T} c^{D} \tilde{S}-\tilde{S}^{T} h \widetilde{D}^{j}+\frac{1}{2} \widetilde{D}^{j T} \beta_{s} \widetilde{D}^{j}\right) \mathrm{d} V_{j}^{s e}
\end{aligned}
$$

gdzie: $\tilde{\mathbf{S}}$ oraz $\widetilde{\mathbf{D}}^{\mathbf{j}}$ - to: wektory odkształceń oraz gęstość ładunku elektrycznego,

$\mathbf{c}_{\text {st }}, \mathbf{C}^{\mathbf{D}}, \mathbf{h}$ - to macierze: stałych sprężystych struktury, stałych sprężystych elementów piezoelektrycznych, stałych piezoelektrycznych przy stałej gęstości ładunku elektrycznego,

$\beta_{S}$ - odwrotność stałej dielektrycznej przy stałym odkształceniu, $\widetilde{\mathbf{S}}^{\mathbf{T}}, \widetilde{\mathbf{D}}^{\mathbf{j} \mathbf{T}}$ - macierze transponowane macierzy $\widetilde{\mathbf{S}}$ oraz $\widetilde{\mathbf{D}}^{\mathbf{j}}$, $V^{s t}, V^{a}, V^{s e}$ - to objętości struktury, piezoelektrycznego elementu wykonawczego oraz piezoelektrycznego elementu pomiarowego, $N_{a}, N_{s e}$ - oznaczają odpowiednio liczbę elementów wykonawczych oraz pomiarowych. 
Lokalny układ współrzędnych dla każdego elementu piezoelektrycznego można transponować do globalnego układu współrzędnych, za pomocą zależności:

$$
\widetilde{\mathbf{S}}=\mathbf{R}_{\mathbf{S}}^{\mathbf{j}} \mathbf{S}, \widetilde{\mathbf{D}}^{\mathbf{j}}=\mathbf{R}_{\mathbf{D}}^{\mathbf{j}} \mathbf{D}^{\mathbf{j}}
$$

gdzie: $\mathbf{R}_{\mathbf{s}}^{\mathbf{j}}, \mathbf{R}_{\mathbf{D}}^{\mathbf{j}}$ - to macierze transformacyjne odkształcenia oraz gęstości ładunku elektrycznego.

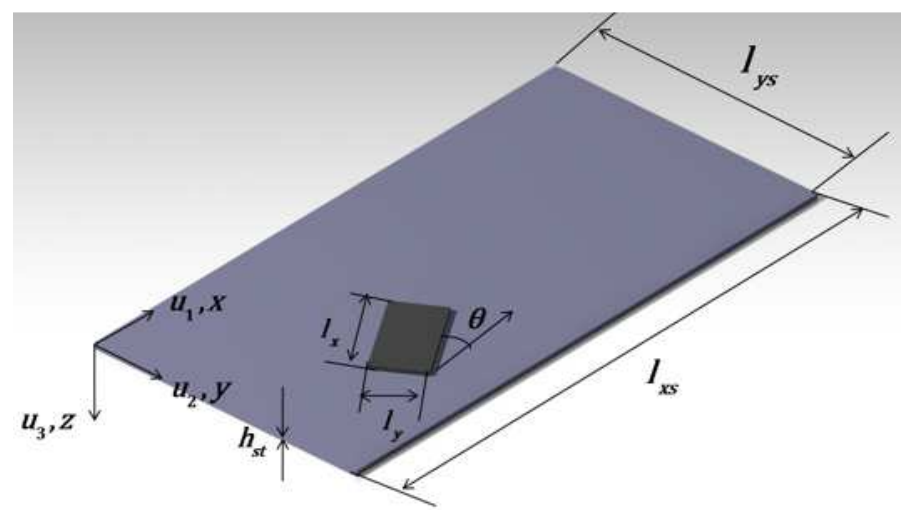

Rys. 1. Orientacja elementów piezoelektrycznych

Fig. 1. Orientation of piezoelectric patches

Do określenia optymalnych lokalizacji piezoelektrycznych elementów pomiarowych oraz wykonawczych umieszczonych na powierzchni swobodnie podpartej płyty, wykorzystano zmodyfikowane kryterium optymalizacji oparte na koncepcji przestrzennej normy $\mathrm{H}_{2}$ [7]. W tej metodzie, proponowane są dwa kryteria określania optymalnego rozmieszczenia piezoelektrycznych elementów pomiarowych oraz wykonawczych, używając przestrzennej sterowności/obserwowalności. W pracy rozważano stan, w którym płyta nie podlega rozszerzaniu w swojej płaszczyźnie i założono, że płyta jest obciążona w warunkach czystego zginania. Uwzględniając to założenie, przestrzennie zdyskredytowane pole przemieszczeń w płaszczyźnie środkowej płyty jest równe:

$$
\mathrm{u}_{1}=0, \mathrm{u}_{2}=0, \mathrm{u}_{3}=\mathbf{N}_{\mathbf{U}_{\mathbf{3}}} \cdot \mathbf{U}_{\mathbf{3}}
$$

Napięcie przyłożone do elementu wykonawczego wynosi:

$$
\mathrm{v}(t)^{a}=\left[\begin{array}{llll}
\mathrm{v}(t)_{1}^{a} & \mathrm{v}(t)_{2}^{a} & \cdots & \mathrm{v}(t)_{N_{a}}^{a}
\end{array}\right]
$$

Zakładając zerowe warunki początkowe oraz zerową wartość zewnętrznych sił mechanicznych (obciążeń), funkcja odwzorowująca płytę przyjmuje postać: 


$$
G(x, y, s)=\sum_{i=1}^{\mathrm{n}} G_{i}(x, y, s)=\sum_{i=1}^{n} \frac{N_{U_{3}}^{i} \gamma_{a}^{i}}{s^{2}+2 \zeta_{i} \omega_{i} s+\omega_{i}^{2}}
$$

gdzie: $N_{U_{3}}^{i}$ jest $i$-tą składową wektora $\mathrm{N}_{\mathrm{U}_{3}}$,

$s_{i}$ - współczynniki tłumienia.

Parametr $\gamma_{a}^{i}$ jest definiowany następująco:

$$
\gamma_{a}^{i}=\left[\left(K_{U q}^{a(1)}\right)_{i}\left(K_{q q}^{a(1)}\right)^{-1}\left(K_{U q}^{a(2)}\right)_{i}\left(K_{q q}^{a(2)}\right)^{-1} \ldots\left(K_{U q}^{a\left(N_{a}\right)}\right)_{i}\left(K_{q q}^{a\left(N_{a}\right)}\right)^{-1}\right]
$$

Norma przestrzenna $\mathrm{H}_{2}$ funkcji odwzorowującej (5) [7] jest równa:

$$
\begin{aligned}
\|G\|_{2}^{2}=\int_{-\infty}^{+\infty} & \int_{0}^{l_{x s}} \int_{0}^{l_{y s}} \operatorname{trace}\{G(j \omega, x, y) \\
& \cdot G(j \omega, x, y)\} \mathrm{d} x \mathrm{~d} y \mathrm{~d} \omega=\sum_{i=1}^{n}\left\|\tilde{G}_{i}\right\|_{2}^{2}
\end{aligned}
$$

gdzie trace $\{\cdot\}$ jest sumą elementów na przekątnej głównej macierzy:

$$
\tilde{G}_{i}=\frac{N_{U_{3}}^{i} \gamma_{a}^{i}}{s^{2}+2 \zeta_{i} \omega_{i} s+\omega_{i}^{2}}, i=1,2, \ldots n
$$

Optymalną lokalizację $j$-tego piezoelektrycznego elementu wykonawczego określa funkcja $\Psi_{i j}$ :

$$
\begin{aligned}
\psi_{i j}\left(x^{a(j)}, y^{a(j)}, \theta^{a(j)}\right)=\left\|\tilde{G}_{i}^{j}\right\|_{2} \\
=\left|\left(K_{U q}^{a(j)}\right)_{i}\left(K_{q q}^{a(j)}\right)^{-1}\right|\left\|\frac{\gamma_{a}^{i}}{s^{2}+2 \zeta_{i} \omega_{i} s+\omega_{i}^{2}}\right\|
\end{aligned}
$$

gdzie: $i=1,2, \ldots n$,

$x^{a(j)}, y^{a(j)}-$ to współrzędne $j$-tego elementu wykonawczego,
$\theta^{a(j)}$ - to orientacja kątowa elementu wykonawczego.

Kątowa orientacja elementu wykonawczego może zmieniać się w zakresie $0 \leq \Theta<\pi$. Optymalizacji poddano następujące zmienne lokalizacyjne piezoelektrycznych elementów:

$$
\left\{\left(x^{a(j)}, y^{a(j)}, \theta^{a(j)}\right)\right\}, j=1,2, \ldots N_{a}
$$


Optymalną lokalizację elementów wykonawczych można określić poprzez maksymalizację następującego kryterium:

$$
\begin{aligned}
& \sum_{j=1}^{N_{a}} \sqrt{\sum_{i=1}^{N_{C}} \psi_{i j}\left(x^{a(j)}, y^{a(j)}, \theta^{a(j)}\right)^{2}} \\
& -\lambda \sum_{j=1}^{N_{a}} \sqrt{\sum_{i=N_{C}}^{N_{C}+N_{R}} \psi_{i j}\left(x^{a(j)}, y^{a(j)}, \theta^{a(j)}\right)^{2}}
\end{aligned}
$$

gdzie: $\lambda$ - to stała korekcyjna,

$N_{C}, N_{R}$ - liczby sterowanych i szczątkowych postaci drgań.

Funkcje $\sum_{i=1}^{N_{C}} \psi_{i j}\left(x^{a(j)}, y^{a(j)}, \theta^{a(j)}\right)^{2}$ oraz $\sum_{i=N_{C}}^{N_{C}+N_{R}} \psi_{i j}\left(x^{a(j)}, y^{a(j)}, \theta^{a(j)}\right)^{2}$ oznaczają: przestrzenną sterowalność pierwszej postaci drgań $N_{C}$ oraz szczątkowej postaci drgań. Uwzględniając, że sterowalność przestrzenna jest taka sama, jak norma przestrzenna $\mathrm{H}_{2}$, to w celu jej wyznaczenia, konieczna jest analiza ograniczonej liczby postaci drgań. Kryterium optymalizacji lokalizacji elementów wykonawczych może być znormalizowane jako:

$$
\begin{aligned}
J_{a}= & \frac{\sum_{j=1}^{N_{a}} \sqrt{\sum_{i=1}^{N_{C}} \psi_{i j}\left(x^{a(j)}, y^{a(j)}, \theta^{a(j)}\right)^{2}}}{\max \sum_{j=1}^{N_{a}} \sqrt{\sum_{i=1}^{N_{C}} \psi_{i j}\left(x^{a(j)}, y^{a(j)}, \theta^{a(j)}\right)^{2}}} \\
& -\lambda \frac{\sum_{j=1}^{N_{a}} \sqrt{\sum_{i=N_{C}}^{N_{C}+N_{R}} \psi_{i j}\left(x^{a(j)}, y^{a(j)}, \theta^{a(j)}\right)^{2}}}{\max \sum_{j=1}^{N_{a}} \sqrt{\sum_{i=N_{C}}^{N_{C}+N_{R}} \psi_{i j}\left(x^{a(j)}, y^{a(j)}, \theta^{a(j)}\right)^{2}}}
\end{aligned}
$$

\section{Optymalizacja lokalizacji i orientacji elementów}

Idea obliczeń za pomocą algorytmów genetycznych opiera się na prawach rządzących ewolucją naturalną, według której największe szanse na przeżycie mają osobniki najlepiej przystosowane do panujących warunków zewnętrznych. Podstawową jednostką zawierająca informacje o danym osobniku są geny zawierające łańcuchy zwane chromosomami. Podstawowymi operacjami genetycznymi są selekcja, krzyżowanie i mutacja. W wyniku procesów ewolucyjnych zaczynają przeważać osobniki lepiej przystosowane do populacji. Jednocześnie zachodzi degradacja osobników najmniej dostosowanych do panującego środowiska. Obok mechanizmu dziedziczenia cech i umierania słabszych osobników istnieje mechanizm mutacji. Algorytmy genetyczne to jedna z popularniejszych 
obecnie metod optymalizacji $[2,10]$. Charakterystykę optymalizacyjnego algorytmu genetycznego przedstawiono w tabeli 1 .

Tabela 1. Charakterystyka algorytmu genetycznego

Table 1. Characteristics of genetic algorithm

\begin{tabular}{|l|l|}
\hline \multicolumn{1}{|c|}{$\begin{array}{c}\text { Termin/ } \\
\text { procedura }\end{array}$} & \multicolumn{1}{c|}{ Opis } \\
\hline $\begin{array}{l}\text { Funkcja } \\
\text { dostosowania }\end{array}$ & \multicolumn{1}{|c|}{ Funkcja optymalizowana, $J_{a}$ w równaniu (12) } \\
\hline Osobnik & $\begin{array}{l}\text { Liczba zmiennych konieczna do ustalenia optymalnej lokalizacji elementów } \\
\text { piezoelektrycznych równa } 3 \times N_{s e} \text { lub } 3 \times N_{a} \text { i odpowiada liczbie osobników }\end{array}$ \\
\hline Populacja & $\begin{array}{l}\text { Jeśli liczba zmiennych lub osobników jest równa odpowiednio } 3 \times N_{s e} \text { lub } 3 \times \\
N_{s e} \text { wtedy populacja jest określona przez macierze } N_{i}=3 \times N_{s e} \text { lub } N_{i}=3 \times N_{a}\end{array}$ \\
\hline Ewaluacja & \multicolumn{1}{|c|}{ Wartość funkcji $J_{a}$ w równaniu (12) wyznaczana jest dla każdej populacji } \\
\hline Selekcja & $\begin{array}{l}\text { Wybór dwóch rodziców wykazujących największą wartość funkcji dostosowa- } \\
\text { nia }\end{array}$ \\
\hline Krzyżowanie & Wybór dwóch rodziców do generacji nowego pokolenia \\
\hline Mutacja & Losowa zmiana genów w chromosomie \\
\hline
\end{tabular}

Zazwyczaj wraz z postępem procesu optymalizacji, w kolejnych pokoleniach, algorytm zbliża się do punktu asymptotycznego funkcji dostosowania, po osiągnięciu którego, kryterium wyszukiwania zatrzymuje się. Do celów optymalizacyjnych, w analizie przyjęto następujące wartości parametrów AG: wielkość populacji - 200, współczynnik krzyżowania - 0,8 liczba pokoleń - 50 . W analizach numerycznych rozważono swobodnie podpartą płytę prostokątną z elementami piezoelektrycznymi umieszczonymi na górnej i dolnej powierzchni. Założono, że elementy piezoelektryczne są idealnie połączone z powierzchnią płyty.

Wykorzystując metodę Rayleigh-Ritza oraz rozwijając poprzeczne przemieszczenie płyty $u_{3}(x, y, t)$ ze względu na zależną od czasu modalną funkcję kształtu spełniającą warunki brzegowe:

$$
u_{3}(x, y, t)=\sum_{\kappa=1}^{k} \sum_{l=1}^{l} N_{u_{3}}^{\kappa \iota}(x, y) U^{\kappa \iota}(t)
$$

oraz uwzględniając, że $N_{U_{3}}^{\kappa \iota}$ jest funkcją kształtu a $U^{\kappa \iota}(t)$ jest przemieszczeniem modalnym, $k$ i $l$ są liczbami odnoszącymi się do form drgań płyty, a liczba półfal $\kappa$ oraz $\imath$ jest określana, odpowiednio w kierunku wzdłużnym $x$ oraz kierunku poprzecznym $y$, możemy zapisać przemieszczenie płyty $u_{3} \mathrm{w}$ formie macierzy:

$$
u_{3}=\left[N_{u_{3}}^{11} N_{u_{3}}^{21} N_{u_{3}}^{31} \ldots N_{u_{3}}^{k l}\right]\left[U^{11} U^{21} U^{31} \ldots U^{k l}\right]^{T}
$$

Dla swobodnie podpartej płyty modalne funkcje kształtu, które wykorzystano w analizie są rozwinięciem podwójnych funkcji harmonicznych: 


$$
N_{U_{3}}^{\kappa \iota}=\sin \left(\frac{\kappa \pi x}{l_{x s}}\right) \sin \left(\frac{l \pi y}{l_{y s}}\right)
$$

gdzie: $l_{x s}$ i $l_{y s}-$ to długość i szerokość płyty prostokątnej.

Wymiary płyty oraz elementów piezoelektrycznych, a także właściwości elementów pomiarowych oraz wykonawczych przedstawiono, odpowiednio w tabeli 2 oraz 3. Właściwości mechaniczne płyty wynoszą: gęstość $\rho=2770$ $\mathrm{kg} \cdot \mathrm{m}^{-3}$, moduł Younga $E=70 \mathrm{GPa}$, współczynnik Poissona $v=0,3$, współczynnik thumienia $\zeta_{i}=0,0002$ dla $i=1, \ldots, n$.

Tabela 2. Wymiary płyty oraz elementu piezoelektrycznego

Table 2. Dimensions of the plate and the piezoelectric element

\begin{tabular}{|l|c|c|}
\hline \multicolumn{1}{|c|}{ Parametr } & Płyta & Element piezoelektryczny \\
\hline Długość na kierunku osi x, m & 1 & 0,08 \\
\hline Długość na kierunku osi y, m & 0,5 & 0,04 \\
\hline Grubość: $h_{s t}, h_{p}, \mathrm{~m}$ & 0,002 & 0,0001 \\
\hline
\end{tabular}

Tabela 3. Właściwości elementów pomiarowych oraz wykonawczych PZT-5H, na podstawie [6]

Table 3. Properties of sensors and actuators of PZT-5H, according to [6]

\begin{tabular}{|l|c|c|}
\hline \multicolumn{1}{|c|}{ Właściwości } & Parametr & Wartość \\
\hline \multirow{2}{*}{ Mechaniczne } & $\begin{array}{c}\text { współczynniki macie- } \\
\text { rzy sztywności }\end{array}$ & $\begin{array}{c}C_{11}^{D}=131,6 \mathrm{GPa}, C_{22}^{D}=131,6 \mathrm{GPa} \\
C_{12}^{D}=131,6 \mathrm{GPa}, C_{66}^{D}=131,6 \mathrm{GPa}\end{array}$ \\
\cline { 2 - 4 } & gęstość & $\rho=7800 \mathrm{~kg} \cdot \mathrm{m}^{-3}$ \\
\hline Elektryczne & stała dielektryczna & $\beta_{33}^{S}=1,48 \cdot 10^{8} \mathrm{~m} \cdot \mathrm{F}^{-1}$ \\
\hline Mechaniczno- & stałe & $h_{13}=-2,72 \cdot 10^{9} \mathrm{~N} \cdot \mathrm{C}^{-1}$ \\
elektryczne & piezoelektryczne & $h_{23}=-2,72 \cdot 10^{9} \mathrm{~N} \cdot \mathrm{C}^{-1}$ \\
\hline
\end{tabular}

W celu aktywnego tłumienia drgań rozważono tylko pięć pierwszych form drgań, których wartości częstotliwość drgań własnych przedstawiono w tabeli 4.

Tabela 4. Pięć pierwszych częstotliwość drgań własnych

Table 4. The first five natural frequencies

\begin{tabular}{|c|c|}
\hline Postać drgań $(\kappa, l)$ & Częstotliwość drgań własnych, Hz \\
\hline$N_{U_{3}}^{11}$ & 23,88 \\
\hline$N_{U_{3}}^{21}$ & 38,22 \\
\hline$N_{U_{3}}^{31}$ & 62,11 \\
\hline$N_{U_{3}}^{12}$ & 81,23 \\
\hline$N_{U_{3}}^{22}$ & 95,57 \\
\hline
\end{tabular}


Przeprowadzono wiele symulacji z użyciem algorytmu genetycznego. W pierwszych dwóch symulacjach rozważano pierwsze dwie formy drgań, które charakteryzowały się najwyższą sterowalnością oraz obserwowalnością, pozostałe trzy formy rozważano jako formy szczątkowe. Ponieważ funkcje dostosowania dla poszukiwanych lokalizacji elementów pomiarowych oraz wykonawczych są podobne, poniżej przedstawiono wyniki analizy tylko dla elementów pomiarowych.

Najlepsze i średnie wartości funkcji dostosowania dla określenia optymalnego położenia elementów pomiarowych przedstawiono na rysunku 2a. Największa wartość funkcji celu jest równa 1,68. Optymalne współrzędne punktu umiejscowienia elementu pomiarowego $\mathrm{w}$ narożu płyty wynoszą $(\mathrm{x}=0,657 \mathrm{~m}, \mathrm{y}$ $=0,206 \mathrm{~m}$ ), orientacja względem dłuższej krawędzi płyty wynosi $52^{\circ}$. Największe i średnie wartości funkcji dostosowania dla określenia lokalizacji pary element pomiarowy/wykonawczy przedstawiono na rysunku $2 \mathrm{~b}$.

W pierwszym pokoleniu wartość funkcji dostosowania szybko wzrasta dlatego, że odpowiadający wartości funkcji dostosowania punkt znajduje się daleko od punktu optymalnego. Optymalne współrzędne punktów położenia elementów wykonawczych/pomiarowych, w sytuacji rozważania trzech pierwszych postaci drgań (pozostałe dwie postaci drgań rozważano jak szczątkowe) przedstawiono w tabeli 5.

Tabela 5. Zoptymalizowane lokalizacje elementów piezoelektrycznych umieszczonych na powierzchni płyty

Table 5. Optimized location of piezoelectric patches attached to the surface of rectangular plate

\begin{tabular}{|c|c|c|}
\hline \multirow{2}{*}{$\begin{array}{c}\text { Liczba elemen- } \\
\text { tów }\end{array}$} & $N_{U_{3}}^{12}, N_{U_{3}}^{22}$ & $N_{U_{3}}^{11}, N_{U_{3}}^{21}, N_{U_{3}}^{31}$ \\
\cline { 2 - 3 } & $\mathrm{x}=0,6577 \mathrm{~m} ; \mathrm{y}=0,2059 \mathrm{~m} ;$ & $\mathrm{x}=0,4819 \mathrm{~m} ; \mathrm{y}=0,2275 \mathrm{~m} ;$ \\
\multirow{2}{*}{1} & $\mathrm{\Theta}=52^{\circ}$ & $\mathrm{\Theta}=123,23^{\circ}$ \\
\hline \multirow{3}{*}{2} & $\mathrm{x}=0,6739 \mathrm{~m} ; \mathrm{y}=0,2059 \mathrm{~m} ;$ & $\mathrm{x}=0,4375 \mathrm{~m} ; \mathrm{y}=0,2155 \mathrm{~m} ;$ \\
& $\mathrm{\Theta}=72,68^{\circ}$ & $\Theta=103^{\circ}$ \\
& $\mathrm{x}=0,3781 \mathrm{~m} ; \mathrm{y}=0,2513 \mathrm{~m} ;$ & $\mathrm{x}=0,4753 \mathrm{~m} ; \mathrm{y}=0,1527 \mathrm{~m} ;$ \\
& $\Theta=155,53^{\circ}$ & $\Theta=85,61^{\circ}$ \\
\hline
\end{tabular}

Do aktywnego tłumienia drgań jest stosowany algorytm sterowania ujemnego prędkościowego sprzężenia zwrotnego. Jest to skuteczny algorytm do zmniejszenia amplitudy oscylacyjnej. Algorytm tego typu stosuje się w taki sposób, że napięcie elementu wykonawczego może być otrzymane poprzez wzmocnienie sygnału i zmianę biegunowości napięcia elementu pomiarowego w następujący sposób:

$$
\mathbf{v}(t)^{\mathrm{a}}=-\mathbf{G}_{\mathbf{C o}} \boldsymbol{\Phi}^{\mathrm{se}}(t)
$$

gdzie: $\mathbf{G}_{\mathbf{C o}}$ - to macierz wzmocnienia, wykorzystana w algorytmie sprzężenia zwrotnego. 

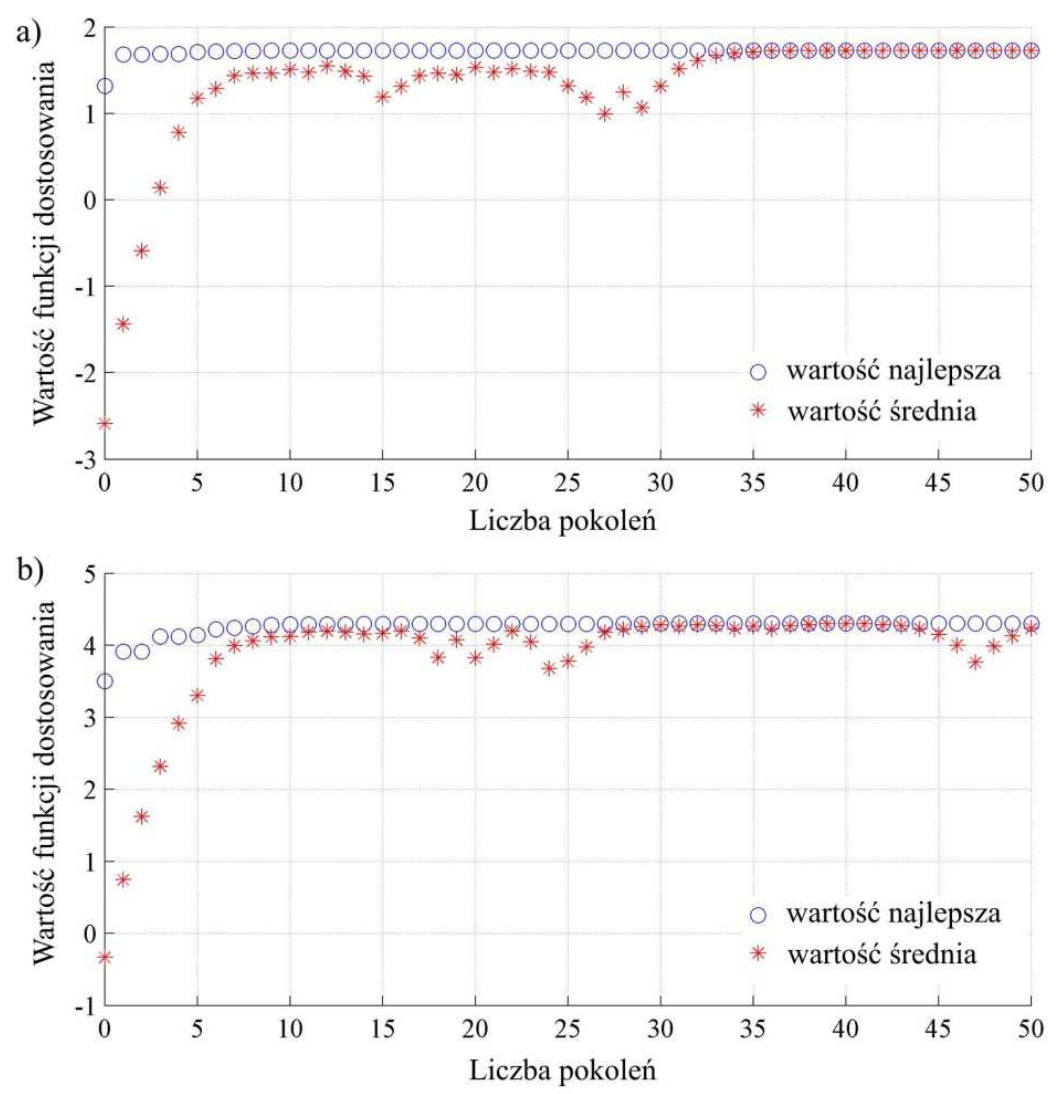

Rys. 2. Zmiana wartości średniej i największej funkcji dostosowania dla znalezienia lokalizacji elementów wykonawczych/pomiarowych uwzględniając dwie pierwsze postaci drgań: a) jeden element wykonawczy/pomiarowy, b) para element wykonawczy/pomiarowy

Fig. 2. Evolution of the mean and best values of fitness function for finding actuator/sensor locations when the first two modes are controlled: (a) one actuator/sensor (b) a pair of actuator/sensor

W pierwszej symulacji rozważano dwie formy drgań, pozostałe trzy formy rozważano jako formy szczątkowe. Ponieważ funkcje dostosowania dla poszukiwanych lokalizacji elementów pomiarowych oraz wykonawczych są podobne, poniżej przedstawiono wyniki analizy tylko dla elementów pomiarowych. Podczas analizy zastosowano funkcję krokową koncentrując obciążenie w miejscu poza środkiem płyty. Odpowiedzi częstotliwościowe płyty, po wzbudzeniu poprzez siłę skupioną, umieszczoną w punkcie o współrzędnych $x=0,43 \mathrm{~m}$ oraz $y$ $=0,21 \mathrm{~m}$ (dla różnej liczby elementów pomiarowych oraz wykonawczych), przedstawiono na rysunku 3 . 
Proces optymalizacji lokalizacji elementów wykonawczych/pomiarowych za pomocą algorytmu genetycznego jest skutecznym zadaniem mającym na celu zmniejszenie amplitudy wibracji. Poprzez odpowiednie rozmieszczenie elementów pomiarowych oraz wykonawczych na powierzchni płyty możliwe jest uzyskanie efektu tłumienia drgań płyty. Gdy elementy wykonawcze są umieszczone w optymalnej lokalizacji, amplituda drgań znacząco zmniejsza się.

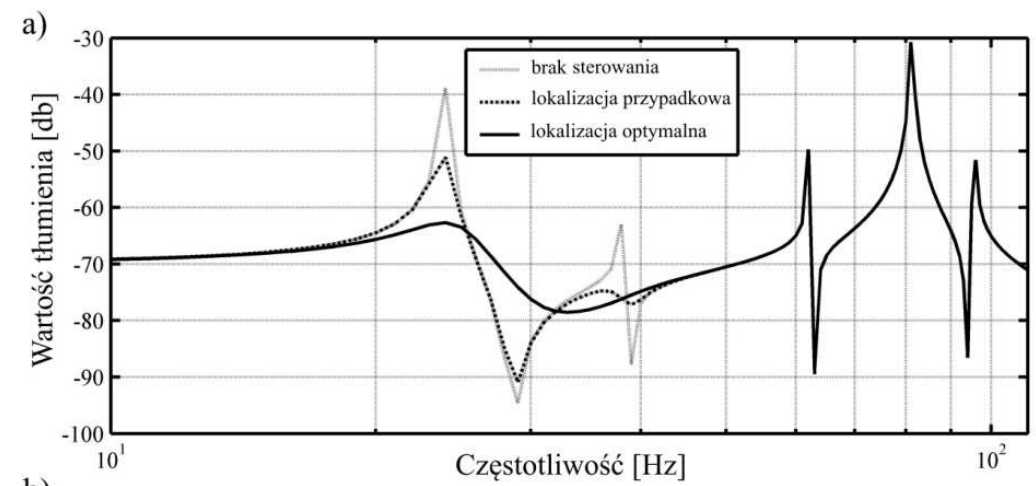

b)

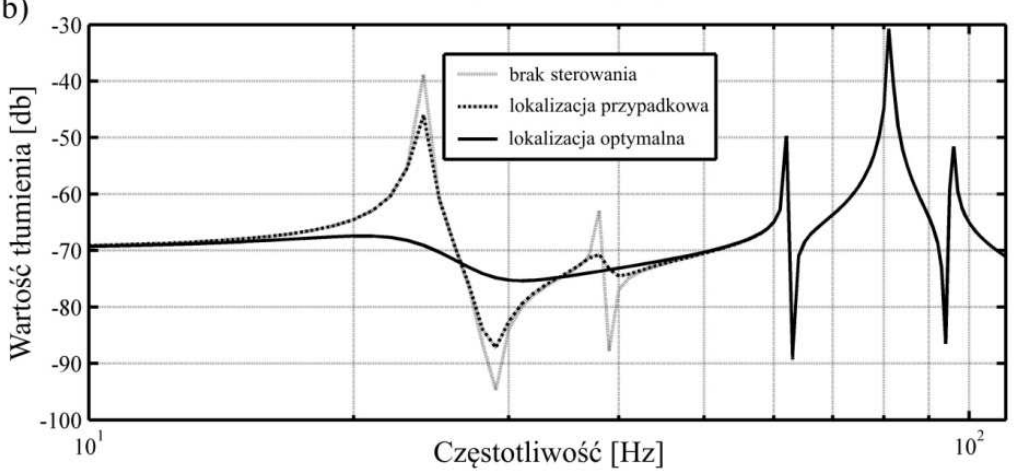

Rys. 3. Odpowiedzi częstotliwościowe płyty sterowanej przez piezoelektryczne elementy wykonawcze/pomiarowe przy rozważaniu dwóch pierwszych form drgań: a) - jeden element wykonawczy/pomiarowy, b) - para element wykonawczy/pomiarowy

Fig. 3. Frequency response of the plate controlled by the piezoelectric actuator/sensor patches when the first two modes are controlled: (a) one actuator/sensor (b) a pair of actuator/sensor

\section{Podsumowanie}

W pracy analizowano procesy aktywnego tłumienia drgań i optymalnego położenia piezoelektrycznych elementów umieszczonych na powierzchni cienkiej płyty prostokątnej. Do wyznaczenia równania ruchu oraz równania sygnałów wyjściowych wykorzystano prawo Hamiltona i metodę Rayleigha-Ritza. W następnym kroku, optymalne lokalizacje i orientacje piezoelektrycznych elemen- 
tów wykonawczych i pomiarowych podłączonych do prostokątnej płytki ustalono w oparciu o koncepcję przestrzennej sterowalności/obserwowalności. Algorytm genetyczny wykorzystano do optymalizacji lokalizacji i orientacji urządzeń piezoelektrycznych. Wyniki wykazały, że poprzez umieszczenie piezoelektrycznych elementów pomiarowych oraz wykonawczych w optymalnym miejscu, można zwiększyć efekt tłumienia i bardziej efektywnie zmniejszyć amplitudę drgań płyty. Wykazano również skuteczność aktywnego tłumienia drgań w analizie wibracji cienkiej płyty.

\section{Literatura}

[1] Bruant I., Gallimard L., Nikoukar S.: Optimal piezoelectric actuator and sensor location for active vibration control, using genetic algorithm, Journal of Sound and Vibration, vol. 329, no. 10, 2010, pp. 1615-1635.

[2] Chiba R., Sugano Y.: Optimisation of material composition of functionally graded materials based on multiscale thermoelastic analysis, Acta Mechanica, vol. 223, no. 5, 2012, pp. 891-909.

[3] Halim D., Reza Moheimani S.O.: An optimization approach to optimal placement of collocated piezoelectric actuators and sensors on a thin plate, Mechatronics, vol. 13, no. 1, 2003, pp. 27-47.

[4] He X.Q., Ng T.Y., Sivashanker S., Liew K.M.: Active control of FGM plates with integrated piezoelectric sensors and actuators, International Journal of Solids and Structures, vol. 38, no. 9, 2001, pp. 1641-1655.

[5] Kumar K.R., Narayanan S.: Active vibration control of beams with optimal placement of piezoelectric sensors/actuator pairs, Smart Materials and Structures, vol. 17 , no. 5, 2008, pp. 055008.

[6] Leo D.J.: Engineering analysis of smart material systems, John Wiley, New York 2007.

[7] Reza Moheimani S.O., Halim D., Fleming A.J.: Spatial control of vibration theory and experiments, World Scientific, New York 2002.

[8] Sadri A.M., Wright J.R., Wynne R.J.: Modelling and optimal placement of piezoelectric actuators in isotropic plates using genetic algorithms, Smart Materials and Structures, vol. 8, no. 4, 1999, pp. 490-498.

[9] Sarangi S.K., Ray M.C.: Active damping of geometrically nonlinear vibrations of laminated composite plates using vertically reinforced 1-3 piezoelectric composites, Acta Mechanica, vol. 222, no. 3-4, 2011, pp. 363-380.

[10] Yang Y., Jin Z., Soh C.K.: Integrated optimal design of vibration control system for smart beams using genetic algorithms, Journal of Sound and Vibration, vol. 282, no. 3-5, 2005, pp. 1293-1307.

[11] Zhang Y.H., Xie S.L., Zhang X.N.: Vibration control of a simply supported cylindrical shell using a laminated piezoelectric actuator, Acta Mechanica, vol. 196, no. $1-2,2008$, pp. 87-101. 


\section{Acknowledgement}

The research leading to these results has received funding from the People Programme (Marie Curie Actions) of the European Union's Seventh Framework Programme FP7/2007-2013/ under REA grant agreement No. PITN-GA-2013- 606878.

\section{ACTIVE VIBRATION DAMPING OF A RECTANGULAR PLATE BY USING PIEZOELECTRIC SENSORS AND ACTUATORS}

\section{S u m m a r y}

In the paper the active vibration damping process of the rectangular plate by using piezoelectric sensors and actuators was analysed. To find the optimal locations and orientations of piezoelectric elements a genetic algorithm was used. To control the vibrations of the plate, a negative velocity feedback control algorithm was designed. Many simulations were carried out to show the usefulness of the genetic algorithm used to optimize the locations and orientations of the piezoelectric elements attached to a thin plate. We suppose that the piezoelectric sensors and actuators are perfectly bonded to the surfaces. During loading analyses we applied the step function concentrating the load at a location off-center of plate. By locating the piezoelectric patches in the optimal positions, the amplitudes of the plate vibrations were reduced. The effect of a number of piezoelectric devices on the property of the active damping system was also analysed. It can be concluded that the damping effect increases and the amplitude of plate vibrations were reduced more effectively because of the use of some of actuators and sensors.

Keywords: actuator, active dumping control, genetic algorithm, piezoelectric sensor, gramian

DOI: $10.7862 / \mathrm{rm} .2015 .29$

Otrzymano/received: 4.09.2015 r.

Zaakceptowano/accepted: 11.10.2015 r. 